\title{
Heterologous Expression of a Mutated Carnation Ethylene Receptor Gene, Dc-ETR1nr, Suppresses Petal Abscission and Autocatalytic Ethylene Production in Transgenic Torenia fournieri Lind.
}

\author{
Koji Tanase $^{1 *}$, Ryutaro Aida ${ }^{1}$, Hiroyasu Yamaguchi ${ }^{1}$, Natsu Tanikawa ${ }^{1}$, Masayasu Nagata ${ }^{2}$, \\ Takashi Onozaki ${ }^{1}$ and Kazuo Ichimura ${ }^{1}$ \\ ${ }^{1}$ National Institute of Floricultural Sciences, National Agriculture and Food Research Organization (NARO), Tsukuba 305-8519, \\ Japan \\ ${ }^{2}$ National Institute of Vegetable and Tea Science, National Agriculture and Food Research Organization (NARO), Tsu 514-2392, Japan
}

The mutated carnation ethylene receptor gene Dc-ETRInr was introduced into Torenia fournieri Lind. This gene contains a missense mutation causing conversion of a $\mathrm{Pro}^{36}$ residue of the carnation ethylene receptor protein De-ETR1 to $\mathrm{Leu}^{36}$, as occurs with the tomato mutant gene Never-ripe $(\mathrm{Nr})$. Agrobacterium transformation of Torenia was performed, and four putative transgenic plants with $D c$-ETR 1 nr were obtained. Real-time RT-PCR analysis confirmed $D c-E T R 1 n r$ mRNA expression in all transgenic plants. Unlike wild-type plants and 1aminocyclopropane-1-carboxylic acid oxidase (ACO) transgenic plants, none of the transgenic plants showed flower abscission in response to ethylene treatment. Flower life in all Dc-ETRInr transgenic plants following wounding or ethylene treatment was longer than that in wild-type plants. Levels of autocatalytic ethylene production in all transgenic plants following wounding or pollination treatment were lower than those in wildtype plants. These results indicate that transgenic plants expressing Dc-ETRInr have reduced ethylene sensitivity, resulting in inhibition of autocatalytic ethylene production and flower senescence.

Key Words: ethylene insensitivity, flower longevity.

\section{Introduction}

Ethylene, a gaseous plant hormone, regulates a number of important physiological and developmental processes, such as germination, abscission, flower senescence, and fruit ripening, in numerous plant species (Abeles et al., 1992; Ahmadi et al., 2008; Woltering and vanDoorn, 1988). The biosynthetic pathway of ethylene is well characterized, as follows: methionine $\rightarrow \mathrm{S}$-adenosylmethionine (AdoMet) $\rightarrow$ 1-aminocyclopropane-1-carboxylate (ACC) $\rightarrow$ ethylene (Kende, 1993). The conversion of AdoMet to ACC is catalyzed by ACC synthase (ACS), and ethylene is made from ACC by ACC oxidase (ACO). Many studies have examined the physiological and molecular mechanisms of the various events regulated

Received; January 5, 2010. Accepted; August 3, 2010.

This study was supported by a grant from the Development of Innovative Crops through the Molecular Analysis of Useful Genes Project of the National Agriculture and Food Research Organization (NARO), Japan.

* Corresponding author (E-mail: tanase@affrc.go.jp). by ethylene. In some flowers, an increase in ethylene production is associated with senescence (Halevy and Mayak, 1981). Exposure of flowers to exogenous ethylene induces autocatalytic ethylene production and flower senescence.

Ethylene perception affects the expression of many genes that are important for biological responses. Ethylene signaling is mediated through ethylene signaling components and is promoted by ethyleneethylene receptor interaction. Through molecular genetic studies of ethylene perception in Arabidopsis thaliana, many ethylene-signaling components have been identified; five ethylene receptors (ETR1, ERS1, ETR2, ERS2, and EIN4) have been identified in Arabidopsis (Chang et al., 1993; Hua and Meyerowitz, 1998; Hua et al., 1998; Sakai et al., 1998). Many ethylene receptor genes have been isolated from other plant species: six genes from tomato $(L e-E T R 1,2,4,5,6$, and $N R)$ and three genes from carnation (Dc-ETRI, Dc-ERSI, and DcERS2) (Adams-Phillips et al., 2004; Klee, 2002; Shibuya et al., 2002). However, ethylene receptor genes have not been identified in Torenia. 
Transgenic plants heterologously expressing the etrl1 gene, a mutated form of ETR 1 from Arabidopsis, show reduced ethylene sensitivity and delayed flower senescence and fruit ripening (Wilkinson et al., 1997). Introduction of the etrl-1 gene extends flower life in petunia, carnation, Campanula carpatica, and Kalanchoe plants (Bovy et al., 1999; Sanikhani et al., 2008; Sriskandarajah et al., 2007; Wilkinson et al., 1997). In the tomato plant, Never-ripe $(\mathrm{Nr})$ is a semi-dominant mutant with a single nucleotide change in an ethylene receptor gene (Wilkinson et al., 1995). The single nucleotide change resulting in a $\mathrm{Pro}^{36}$ to $\mathrm{Leu}^{36}$ substitution in the hydrophobic region of NR protein is sufficient to confer ethylene insensitivity in the $\mathrm{Nr}$ mutant. Fruits of the $N r$ mutant are incapable of ripening, and antisense inhibition of the $\mathrm{Nr}$ gene restores normal ripening to the fruits (Hackett et al., 2000).

Torenia fournieri Lind., commonly known as torenia, is an important ornamental plant, especially as a bedding plant in the summer, because of its high-temperature tolerance. It can be easily propagated and produces many uniform flowers. The flowers normally abscise 1 week after anthesis, but some flowers abscise within a few days. One of the factors involved in abscission is wounding or pollination by, for example, insects and slugs. Wounding or pollination accelerates ethylene production by Torenia flowers (Goto et al., 1999). In ethylene-sensitive flowers, including Torenia, flower senescence is regulated by ethylene (Goto et al., 1999). These flowers show a climacteric-like increase in ethylene content, which is caused by an autocatalytic reaction. Torenia flower longevity after wounding is increased by introducing sense and antisense ACO genes (Aida et al., 1998). ACO mRNA levels and ethylene production are reduced in the ACO transgenic plants. The 379-433 co-suppression mutant line has the longest flower life (7 days) among all ACO transgenic plants. However, flower senescence may be accelerated by exogenous ethylene.

Here, we produced transgenic Torenia plants and examined the effect of the mutant ethylene receptor gene $D c-E T R I n r$ on flower longevity following wounding, pollination, or ethylene treatment in transgenic Torenia plants. Additionally, we compared Dc-ETRInr transgenic plants and ACO transgenic plants and demonstrated the difference between them during flower senescence.

\section{Materials and Methods}

\section{Plant materials and growth condition}

The Torenia cultivar 'Crown Mix' was used for experiments on wild type and Dc-ETRInr transgenic plants. Another cultivar, 'Crown Blue and White', was used for the experiments on ACO transgenic plants. Flower longevity of wild-type plants in these cultivars was the same (data not shown), but the flower color was different. Transgenic plants and wild-type plants were grown on solid Murashige and Skoog (MS) medium at $25^{\circ} \mathrm{C}$ in a 16 -h light-8-h dark photoperiod (Aida, 2008). Plants were transferred to a rockwool block and placed in a containment greenhouse at 15 to $30^{\circ} \mathrm{C}$ under natural daylight conditions.

\section{Transformation and confirmation of transgenic plants}

$D c-E T R I n r$, in which a missense mutation was introduced into the carnation ethylene receptor gene, $D c$ ETR1, converting $\mathrm{Pro}^{36}$ to $\mathrm{Leu}^{36}$ in the encoded protein (Fig. 1A), as in the tomato mutant ethylene receptor gene $\mathrm{Nr}$, was obtained by a site-specific mutagenesis using an overlap extension method (Higuchi et al., 1988; Ho et al., 1989). Plasmid pBIDc-ETR1nr contained the neomycin phosphotransferase (NPT) gene under the control of the nopaline synthase (nos) promoter and the Dc-ETRInr gene under the control of the CaMV $35 \mathrm{~S}$ promoter. Transformants containing pBIDc-ETR1nr were selected on the MS media plus kanamycin. Plants were transformed with Agrobacterium tumefaciens as previously reported (Aida, 2008; Aida et al., 1998). To confirm the presence of Dc-ETR $1 n r$, PCR was performed with genomic DNA from the transgenic plants and wildtype plants using the primers Dc-ETRInr forward (arrow 1 in Figure 1A; 5'-GCA AAT GGA GCT TCG ACT TAG-3') and Dc-ETR Inr reverse (arrow 2 in Figure 1A; 5'-TTC ACA CCG TTT CAA CTC CC-3'). The PCR conditions used were $95^{\circ} \mathrm{C}$ for $5 \mathrm{~min} ; 40$ cycles of $30 \mathrm{~s}$ at $94^{\circ} \mathrm{C}, 45 \mathrm{~s}$ at $60^{\circ} \mathrm{C}$, and $30 \mathrm{~s}$ at $72^{\circ} \mathrm{C}$; and $7 \mathrm{~min}$ at $72^{\circ} \mathrm{C}$. ACO transgenic plants that contain an ACO transgene have been produced previously (Aida et al., 1998). The 379-433 line, which has the longest flower life among all ACO transgenic plants, was used for the experiments.

Determination of flower longevity after wounding or ethylene treatment and of ethylene production after wounding or pollination treatment

The vase life of each flower was determined from anthesis; the end of life was defined as when a corolla showed either wilting with abscission or browning of the corolla margin without abscission. For wounding, a stigma including the upper part of a style was crushed five times with a small pair of tweezers. Ethylene treatment was performed as follows: flowers were harvested when the corolla was open (day 0). The stems of these flowers were placed in distilled water at $23^{\circ} \mathrm{C}$ with a 12-h light-12-h dark photoperiod. The next day (day 1) flowers were placed in a 70-L chamber with $10 \mu \mathrm{L} \cdot \mathrm{L}^{-1}$ ethylene under continuous light conditions. After $24 \mathrm{~h}$, abscission of the corolla was checked and flowers were placed in the evaluation room at $23^{\circ} \mathrm{C}$ in a 12-h light-12-h dark photoperiod. Quantification of ethylene production was performed as previously reported (Tanase et al., 2008). For pollination treatment, flowers were pollinated on day 0 with freshly collected pollen from wild-type plants. 


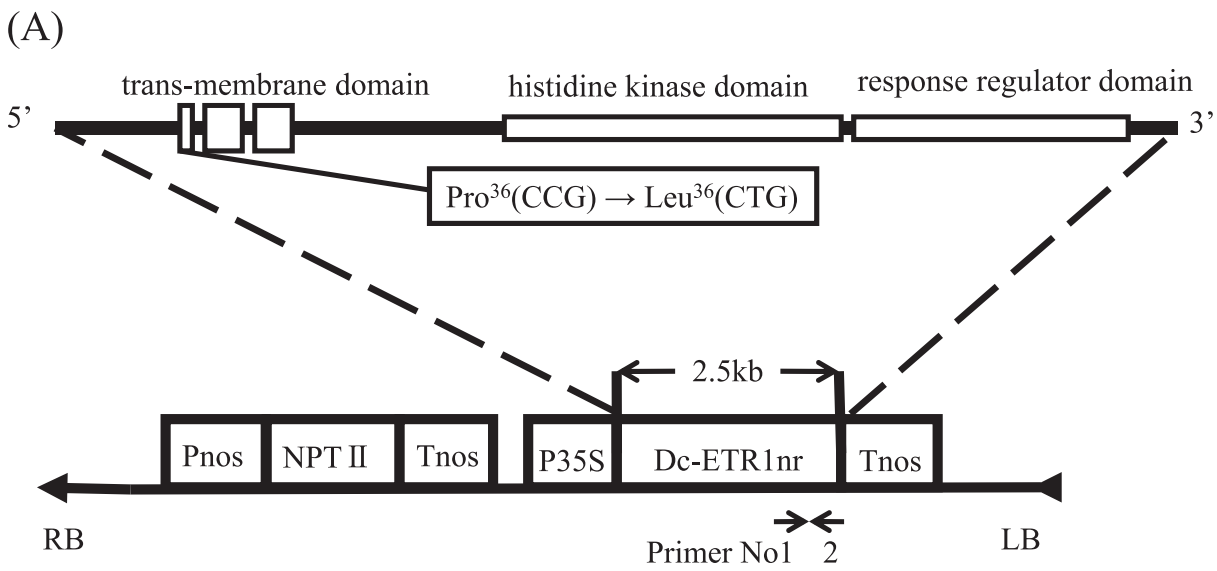

(B)

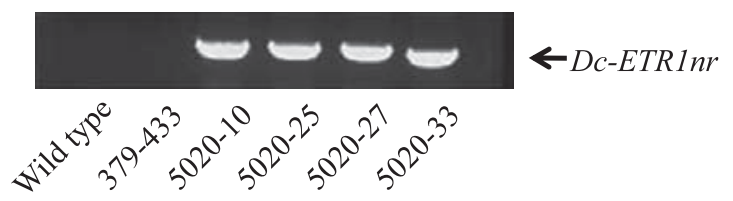

Fig. 1. (A) Construction of the transformation vector pBIDc-ETR1nr. RB and LB, right and left borders, respectively, of T-DNA; Pnos, nopaline synthase promoter; NPT II, neomycin phosphotransferase gene; Tnos, nopaline synthase terminator; $\mathrm{P} 35 \mathrm{~S}$, CaMV $35 \mathrm{~S}$ promoter. To confirm the presence of the Dc-ETRInr transgene, the arrowed primers 1 and 2 (see text) were used in PCR. (B) The presence of the transgene in the putative transformants was confirmed by genomic PCR. 379-433, ACO transgenic plant; 5020-10, 5020-25, 5020-27, 5020-33, DcETRInr transgenic plant.

Cloning of cDNAs coding for the ethylene receptor in Torenia

cDNA fragments encoding for the ethylene receptor were amplified by RT-PCR using the following primers: forward, 5'-TTC/T ATA/T/C GTA/G/C/T CTA/G/C/T TGT GGA GCA/G/C/T ACA/G/C/T CA-3', and reverse, 5'-CAT A/G/C/TGG A/G/C/TGT C/TCT/G CAT C/TTC A/GTG A/GTT CAT-3'. Amplified DNA fragments were cloned into pT7Blue (Novagen, Madison, USA) and confirmed to be ethylene receptor cDNA by DNA sequencing. 5'-RACE and 3'-RACE were performed essentially in accordance with the manufacturer's instructions, using a kit from Takara Bio (Kyoto, Japan).

\section{Isolation of RNA and quantitative reverse-transcription PCR (RT-PCR)}

We used real-time RT-PCR analysis to determine the amount of Dc-ETRInr transcript in flowers. Flowers were harvested at day 0 . Total RNA was extracted from the flowers with an RNeasy Plant Mini Kit (Qiagen, Hilden, Germany); $1 \mu \mathrm{g}$ of the total RNA was used to synthesize first-strand cDNA by using oligo (dT) primer and reverse transcriptase with an Advantage RT-for-PCR kit (Clontech Laboratories, Inc., Mountain View, USA). To confirm the amount of template RNA, a fragment of Torenia actin3 (Tf-ACT3; DDBJ Accession No. AB330989) was used as an internal control.

Real-time RT-PCR was performed with a LIGHTCYCLER model 3.1 System (Roche Diagnostics, Mannheim, Germany). The following primers were used:
$D c$-ETRInr forward and Dc-ETRInr reverse, described above; Tf-ETRI forward (5'-GTA ACG ACC GCT TCT TCT GG-3'), Tf-ETR 1 reverse (5'-AAG GGG CCT ATC GTG ACT CTC-3'); and $T f-A C T 3$ forward (5'-TGC AGT AAA GTG TAT TGT GGA AG-3'), Tf-ACT3 reverse (5'GGA ACT ATC TGG GTA GGA TC-3'). PCR was performed by the following programs: 30 cycles each at $94^{\circ} \mathrm{C}$ for $10 \mathrm{~s}, 57^{\circ} \mathrm{C}$ for $15 \mathrm{~s}$, and $72^{\circ} \mathrm{C}$ for $20 \mathrm{~s}$ for $D c-$ ETRInr; 30 cycles at $94^{\circ} \mathrm{C}$ for $10 \mathrm{~s}, 60^{\circ} \mathrm{C}$ for $5 \mathrm{~s}$, and $72^{\circ} \mathrm{C}$ for $15 \mathrm{~s}$ for $T$-ETR 1 ; and 30 cycles at $94^{\circ} \mathrm{C}$ for $10 \mathrm{~s}, 60^{\circ} \mathrm{C}$ for $10 \mathrm{~s}$, and $72^{\circ} \mathrm{C}$ for $15 \mathrm{~s}$ for $T f-A C T 3$. Amplification of PCR products was monitored via intercalation of SYBR-Green. Data are shown as means $\pm \mathrm{SE}$ of three determinations for each sample.

\section{Observation of adventitious root formation}

Transgenic plants and wild-type plants were grown on solid MS medium at $25^{\circ} \mathrm{C}$ with a 16 -h light-8-h dark photoperiod. Stems of each plant were cut and then cultured on solid MS medium under the same conditions. Adventitious root formation was observed after 18 days. Root formation of six stems of each line was observed.

\section{Results}

\section{Transformation and real-time RT-PCR analysis}

$D c-E T R 1$, which codes for an ethylene receptor, was cloned from carnation (Nagata et al., 2000). Dc-ETR1 has a putative hydrophobic N-terminal domain, a histidine protein kinase domain, and a receiver domain, as in Arabidopsis ETR1. A missense mutation was 
introduced into the Dc-ETRl gene and used for this study. Transgenic Torenia plants that contained the mutated carnation ethylene receptor Dc-ETRInr were generated (Fig. 1A). Thirty-three independent transformants containing Dc-ETRInr were selected on the basis of kanamycin resistance. All four independent putative transformed plants were subjected to genomic-PCR analysis to determine the presence of transgenes; the four lines (5020-10, 5020-25, 5020-27, and 5020-33) were PCR positive (Fig. 1B).

(A)

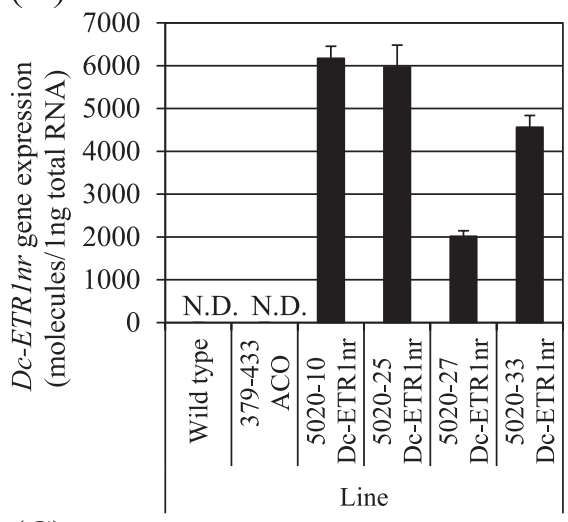

(C)

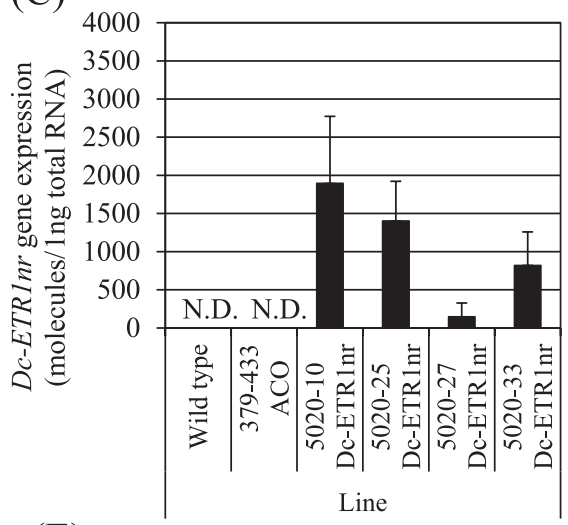

(E)

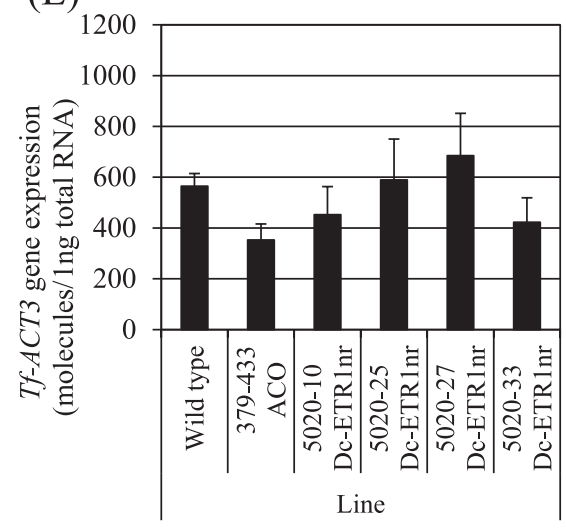

Real-time RT-PCR analysis was performed to investigate the expression of the introduced Dc-ETRInr gene in the transgenic plants. Dc-ETRInr mRNA was expressed in all four independent transformants examined, but not in the wild-type plants nor in the 379433 plants containing the ACO transgene (line 379-433) (Aida et al., 1998). In the flowers, the level of Dc-ETRInr in 5020-10 plants was the highest among all transformants, and the level in 5020-27 was the lowest (Fig. 2A). We cloned an endogenous ethylene receptor

(B)

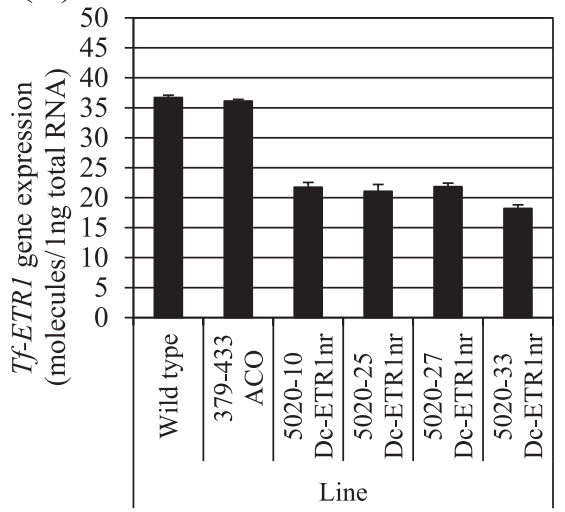

(D)

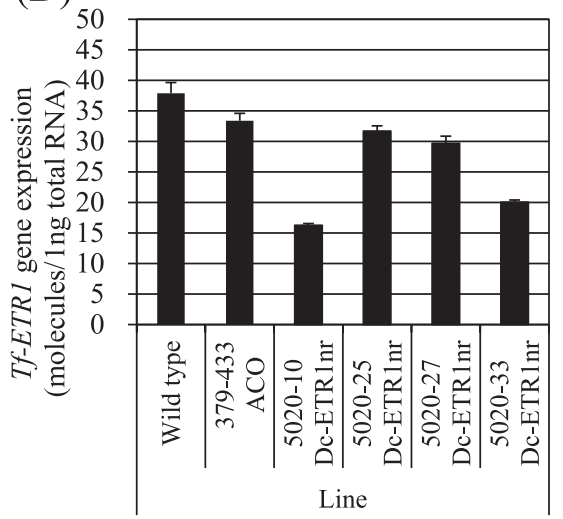

(F)

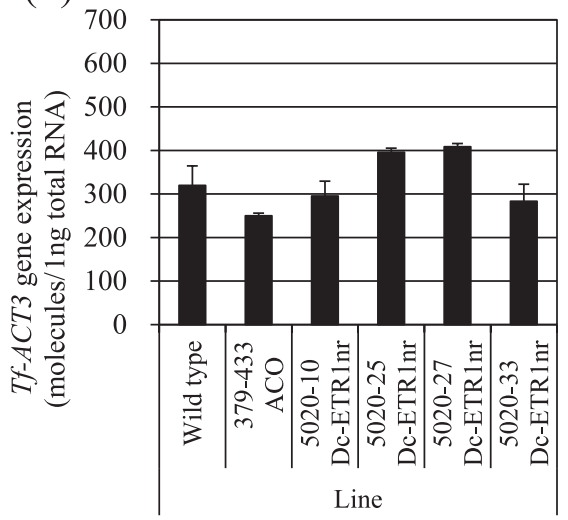

Fig. 2. Quantitative RT-PCR analysis of Dc-ETRInr gene expression in transgenic plants. Flowers were harvested on day 0 . Data represent the results of three independent experiments $( \pm \mathrm{SE})$. (A) Quantitative RT-PCR analysis of Dc-ETR Inr gene expression in flowers of transgenic Torenia plants. N.D., not detected. (B) Quantitative RT-PCR analysis of Tf-ETR1 gene expression in flowers of transgenic Torenia plants. (C) Quantitative RT-PCR analysis of Dc-ETRInr gene expression in stems of transgenic Torenia plants. N.D., not detected. (D) Quantitative RT-PCR analysis of Tf-ETR1 gene expression in stems of transgenic Torenia plants. (E) Quantitative RT-PCR analysis of Tf-ACT3 gene expression in flowers of transgenic Torenia plants. (F) Quantitative RT-PCR analysis of Tf-ACT3 gene expression in stems of transgenic Torenia plants. 


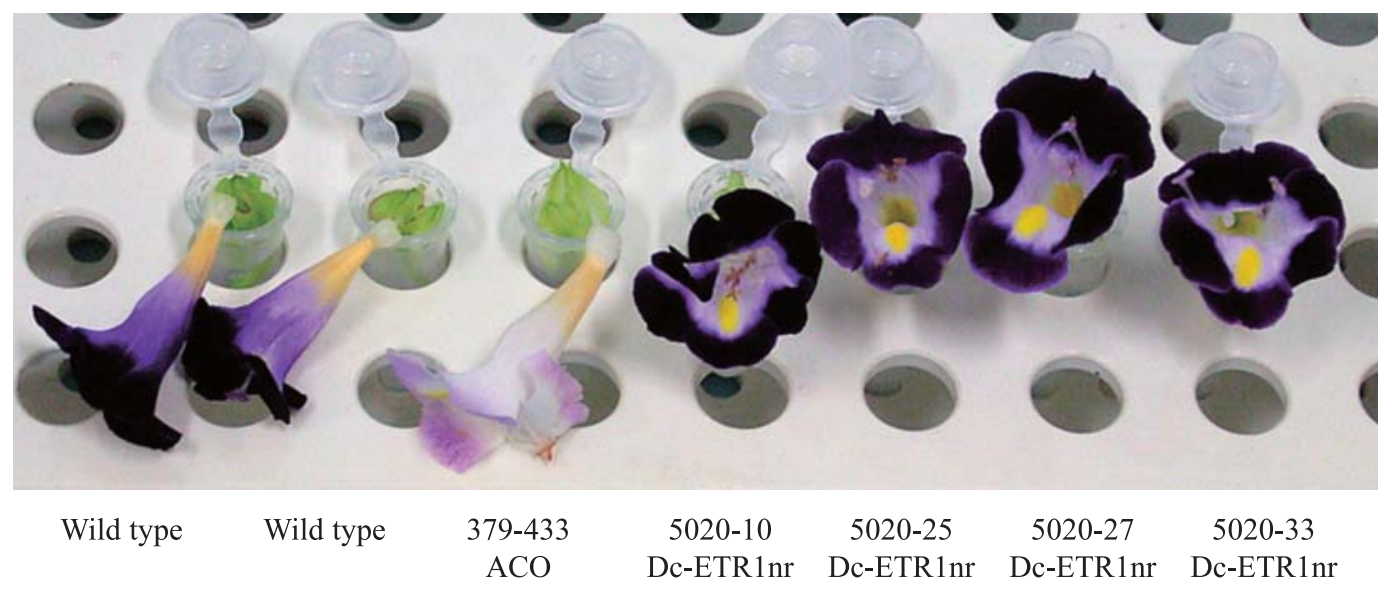

Fig. 3. Comparison of ethylene sensitivities of the wild type and transformant plants. Flowers were treated with $10 \mu \mathrm{L} \cdot \mathrm{L}^{-1}$ ethylene for $24 \mathrm{~h}$.

gene, Tf-ETR1, from Torenia flowers and investigated the levels of Tf-ETR $1 \mathrm{mRNA}$ in wild-type and transgenic plants (Fig. 2B). The deduced amino acid sequence of Tf-ETR1 had a high level of identity to ETR1 of Arabidopsis (data not shown). The levels of Tf-ETRI in the flowers of Dc-ETRInr transgenic plants were lower than those in the flowers of wild-type plants and ACO transgenic plants and were almost the same among the four Dc-ETRInr transgenic lines. In the stems, the level of Dc-ETRInr in the 5020-10 plants was the highest among all transformants, and the level in 5020-27 was the lowest (Fig. 2C). The levels of Tf-ETRI in the stems of 5020-10 and 5020-33 plants were lower than those in the stems of the wild type plants, ACO transgenic plants, and 5020-25 and 5020-27 plants (Fig. 2D). Levels of $T f-A C T 3$, as an internal control, are shown in Figure 2E (flowers) and 2F (stems).

\section{Ethylene sensitivity of flowers in transgenic plants}

Petals of all flowers in wild-type plants and ACO transformants were abscised within 1 day after the start of ethylene treatment (Fig. 3, Table 1). In contrast, the four transformants expressing Dc-ETRInr did not show petal abscission on day 1, although they showed browning of the corolla margin. Flower senescence of Dc-ETR Inr transformants was delayed by 6.3 to 9.0 days compared with that of wild-type and 379-433 flowers after ethylene treatment (Table 1). The flower life of 5020-10 plants was the longest among all the Dc-ETRInr transformants, and that of 5020-27 was the shortest.

\section{Adventitious root formation in transgenic lines}

Formation of adventitious roots in wild-type and transgenic plants was investigated because plants require ethylene for adventitious root formation (Clark et al., 1999). There were significant differences between the four Dc-ETRInr transformants and the wild-type plants and ACO transformants in the number of adventitious roots generated on the lower portions of the plant stems (Fig. 4). Wild-type plants and ACO transformants
Table 1. Flower longevity following stigma wounding or ethylene treatment of Torenia flowers.

\begin{tabular}{|c|c|c|}
\hline \multirow{2}{*}{ Lines (transgene) } & \multicolumn{2}{|c|}{ Flower longevity (days) } \\
\hline & Wounding $^{x}$ & Ethylene treatment ${ }^{y}$ \\
\hline Wild type & $2.6 \pm 0.2$ & $1.0 \pm 0.0$ \\
\hline $379-433(A C O)$ & $7.0 \pm 0.9$ & $1.0 \pm 0.0$ \\
\hline 5020-10 (Dc-ETR Inr $)$ & $10.3 \pm 1.5$ & $10.0 \pm 0.3$ \\
\hline 5020-25 (Dc-ETRInr) & $9.4 \pm 1.0$ & $8.0 \pm 0.0$ \\
\hline 5020-27 (Dc-ETRInr) & $5.1 \pm 0.9$ & $7.3 \pm 1.1$ \\
\hline 5020-33 (Dc-ETRInr) & $8.1 \pm 1.0$ & $8.0 \pm 0.4$ \\
\hline
\end{tabular}

${ }^{x}$ For wounding, a stigma including the upper part of a style was crushed five times with a small pair tweezers on day 0 . Each value is the mean $\pm \mathrm{SE}$ of eight flowers.

${ }^{y}$ Flowers were harvested when the corolla was open (day 0 ) and their stems placed in distilled water. The next day (day 1) flowers were placed in a $70-\mathrm{L}$ chamber with $10 \mu \mathrm{L} \cdot \mathrm{L}^{-1}$ ethylene. After $24 \mathrm{~h}$, flowers were placed in the evaluation room. Each value is the mean $\pm \mathrm{SE}$ of five flowers.
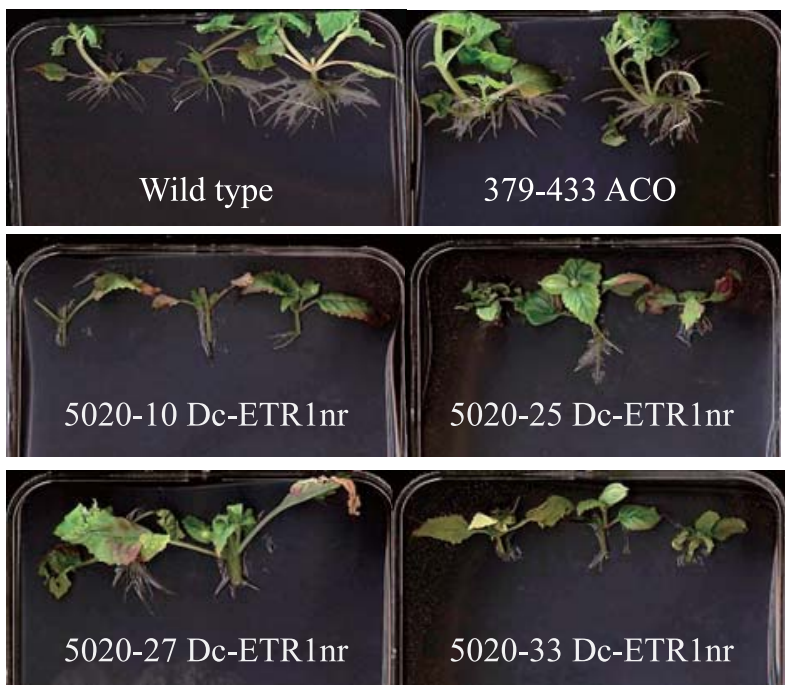

Fig. 4. Formation of adventitious roots in wild type and transformant plants. Stems of each plant were cut and then cultured on solid MS medium at $25^{\circ} \mathrm{C}$ under a 16 -h light-8-h dark photoperiod. After 18 days, adventitious root formation was examined in two or three stems of each line. 
Table 2. Number of adventitious roots in Torenia.

\begin{tabular}{lc}
\hline \hline Line (transgene) & Number of adventitious roots $^{\mathrm{x}}$ \\
\hline Wild type & $15.8 \pm 2.3$ \\
$379-433(A C O)$ & $18.0 \pm 1.7$ \\
$5020-10($ Dc-ETRlnr $)$ & $1.3 \pm 1.1$ \\
$5020-25($ Dc-ETRlnr $)$ & $4.0 \pm 1.9$ \\
$5020-27(D c-E T R 1 n r)$ & $4.3 \pm 3.6$ \\
$5020-33($ Dc-ETRlnr $)$ & $1.0 \pm 0.7$ \\
\hline
\end{tabular}

${ }^{\mathrm{x}}$ Each value is the mean $\pm \mathrm{SE}$ of six plants.

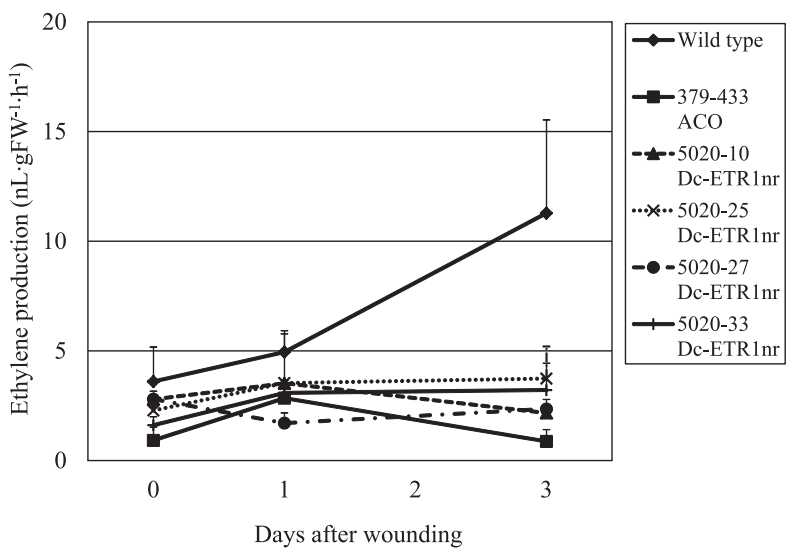

Fig. 5. Ethylene production by Torenia flowers after wounding. Data represent the results of three independent experiments $( \pm \mathrm{SE})$.

produced many more roots on the stems than did the Dc-ETRInr transformants (Table 2).

Analysis of flower longevity and ethylene production

To analyze the effects of the introduced Dc-ETRlnr gene on flower longevity, flower senescence was evaluated visually after wounding treatment (Table 1). The flower longevity of the four Dc-ETRInr transformants was 5.1 to 10.3 days; senescence was delayed by 2.5 to 7.7 days compared with that in wild-type flowers. The flower longevity of the 5020-10, 5020-25, and 502033 transformants was longer than that of the ACO transformants. Flowers of the wild type abscised after treatment, whereas flowers of Dc-ETRInr and ACO transformants showed browning and senesced.

Ethylene production by flowers after wounding or pollination treatment was measured (Fig. 5, Table 3). Ethylene production by flowers on days 0 and 1 after wounding was low and constant in all plants. However, by day 3 there were differences between the four $D c$ ETR Inr transformants and the wild-type plants and ACO transformants (379-433): ethylene production by wildtype flowers was much higher than that by Dc-ETRInr and ACO transformants. On day 1, wounded flowers of ACO transformants produced less ethylene than those of the Dc-ETRInr transformants, with the exception of line 5020-27 (Fig. 5). Flowers of the four Dc-ETRInr transformants produced approximately steady-state levels of ethylene from days 1 to 3 after wounding.
Table 3. Ethylene production by Torenia flowers on day 3 after pollination.

\begin{tabular}{lc}
\hline \hline Line (transgene) & Ethylene production ${ }^{\mathrm{x}}\left(\mathrm{nL} \cdot \mathrm{g} \mathrm{FW}^{-1} \cdot \mathrm{h}^{-1}\right)$ \\
\hline Wild type & $5.0 \pm 0.8$ \\
$379-433($ ACO $)$ & $1.9 \pm 1.3$ \\
$5020-10($ Dc-ETR $1 n r)$ & $3.5 \pm 2.4$ \\
$5020-25($ Dc-ETR $1 n r)$ & $3.5 \pm 0.1$ \\
$5020-27($ Dc-ETR $1 n r)$ & $1.7 \pm 0.5$ \\
$5020-33($ Dc-ETR $1 n r)$ & $3.1 \pm 0.6$ \\
\hline
\end{tabular}

${ }^{x}$ Each value is the mean $\pm \mathrm{SE}$ of three flowers.

Ethylene production on day 3 after pollination was highest in the wild type and lower in the ACO transformants than in the other transformants, with the exception of 5020-27 (Table 3).

\section{Discussion}

On the basis of our knowledge of the mutation in the tomato $\mathrm{Nr}$ gene, a missense mutation causing $\mathrm{Pro}^{36}$ to Leu $^{36}$ was introduced into carnation plants homologous for the ETR1 gene Dc-ETR1 to create the mutant gene $D c-E T R 1 n r$ (Fig. 1A), which was then introduced into T. fournieri plants. Dc-ETRInr transgenic plants expressing Dc-ETRInr under the control of the CaMV $35 \mathrm{~S}$ promoter showed no petal abscission in response to ethylene treatment, resulting in extended flower longevity, as previously observed in transgenic petunia, Nemesia strumosa, Kalanchoe, and carnation plants (Bovy et al., 1999; Cui et al., 2004; Sanikhani et al., 2008; Wilkinson et al., 1997). These results suggest that introducing the $N r$-type mutation into the ethylene receptor gene is useful for modifying ethylene receptors that have been isolated from other plant species. In $N$. strumosa plants, introduction of $\mathrm{Cm}-\mathrm{ETR} 1 / \mathrm{H} 69 \mathrm{~A}$ in which a missense mutation of $\mathrm{His}^{69}$ to $\mathrm{Ala}^{69}$ had been introduced into the melon ETRI gene, Cm-ETRI, reduced ethylene sensitivity (Cui et al., 2004). Shaw et al. (2002) reported that introducing a mutated Brassica oleracea ERS gene, as in the Arabidopsis etr1-4, prolonged flower life in petunia. A hydrophobic domain at the N-terminus of ETR1 is necessary and sufficient for ethylene-binding activity, which is mediated by copper ion (Rodriguez et al., 1999). This highly conserved hydrophobic domain also mediates ethylene binding in the Arabidopsis ERS1 receptor. ETR1 protein with mutation of $\mathrm{Cys}^{65}$ to Ser, and $\mathrm{His}^{69}$ to Ala, lacks ethylene-binding activity. Thus, a missense mutation of $D c$-ETR1 might reduce ethylene-binding to the protein and confer ethylene insensitivity to transgenic plants expressing the mutated receptor gene.

Flower longevity of Torenia plants is prolonged by introducing the antisense ACO gene, and this is accompanied by a reduction in ethylene production (Aida et al., 1998). Ethylene is necessary for adventitious root formation, because ethylene inhibitors reduce the abundance of adventitious roots in some plant species 
(Clark et al., 1999). However, adventitious root formation in ACO transformants of Torenia was not inhibited (Fig. 4), although levels of TORENIA-1, one of the $A C O$ genes, were reduced (Aida et al., 1998). Thus, it is possible that ethylene biosynthesis is not completely blocked in ACO transgenic plants. Torenia might have some $A C O$ genes in its genome, because Southern blot analysis has shown three bands that might be derived from endogenous $A C O$ genes in wild-type Torenia plants (Aida et al., 1998). Dc-ETRInr transgenic plants showed suppression of adventitious root formation and grew slower than wild-type plants after rooting (Fig. 4), although they grew normally on the rockwool block following the generation of a few adventitious roots (data not shown). This suppression in Dc-ETRInr transgenic plants can be attributed to high levels of $D c$ ETRInr expression, because the levels of Dc-ETRInr in the stems of transgenic plants were higher than those of Tf-ETRl (Fig. 2C, D). There were no differences in flower shape or size between Dc-ETRInr transgenic plants and wild-type plants. Carnation and Campanula plants transformed with a construct containing the etr 1-1 gene under the control of the flower-specific $f b p l$ promoter from petunia show increased flower life (Bovy et al., 1999; Sriskandarajah et al., 2007). There are no alterations in morphology or root formation ability in these Campanula plants. Therefore, with the use of $D c$ ETRInr under the control of a flower-specific promoter, there may be no interference with adventitious root formation. Insertion of the etrl-1 gene under the control of the constitutive $\mathrm{CaMV} 35 \mathrm{~S}$ promoter resulted in ethylene-insensitive plants with delayed flower senescence. However, such ethylene-insensitive plants have undesirable qualities, such as reduction in adventitious root formation, high levels of sensitivity to some pathogens, and reduced fruit set and fruit ripening (Clarke et al., 1999; Ohtsubo et al., 1999). Tissue-specific ethylene insensitivity will therefore be a better approach to conquering such problems.

In ACO transgenic Torenia, ethylene production was not completely inhibited (Table 3, Fig. 5). Thus, petal browning appears to be induced by small amounts of endogenous ethylene. Although Dc-ETRInr transgenic plants produced small amounts of ethylene (Table 3, Fig.5), their sensitivity to ethylene was markedly reduced (Table 1). The extension of flower longevity in $D c-E T R 1 n r$ transgenic plants can be attributed to the high levels of Dc-ETRInr expression, which in the flowers were about 100 times those of Tf-ETR1 (Fig. 2A, $B)$. Therefore, the reduced ethylene sensitivity conferred by $D c-E T R I n r$ is very effective in extending flower life.

Ethylene production by flowers is increased by pollination, wounding, ethylene treatment, and senescence in many plants. Autocatalytic ethylene production occurred 3 days after pollination or wounding in flowers of wild-type Torenia plants (Table 3, Fig. 5). In DcETRInr transgenic plants, autocatalytic levels of ethylene production after wounding or pollination were low and maintained at steady state levels. These results suggest that the Dc-ETRInr transgene suppresses autocatalytic ethylene production after wounding or ethylene treatment. In carnation, $D c-A C O 1$ gene expression is reduced in ethylene-insensitive transgenic plants (Bovy et al., 1999). However, their study did not report on ethylene production after pollination or ethylene treatment. In contrast, pollination-induced ethylene production, which is observed in the few hours following pollination, is higher in ethylene-insensitive petunia transformants than in wild-type plants (Wilkinson et al., 1997). There may be a mechanism in ethylene-insensitive transgenic flowers for feedback control of ethylene synthesis after pollination. This feedback control has been observed in the leaves of Arabidopsis etr 1-1 plants (Bleecker et al., 1988; Schaller et al., 1995). Two peaks of ethylene production are observed in petunia plants during long-term observation after pollination (Singh et al., 1992). The first peak, detected a few hours after pollination, is due to ACC present in the pollen, whereas the second peak, observed 2 or 3 days after pollination, results from autocatalytic ethylene production. Autocatalytic ethylene production during natural senescence is affected by ethylene insensitivity in petunia transformants (Langston et al., 2005). These results suggest that autocatalytic ethylene production is inhibited in the flowers of Dc-ETRInr transgenic plants, but that ethylene production induced by other factors such as pollination or wounding is not necessary inhibited in these flowers.

In conclusion, we have demonstrated that an $N r$-type mutation induced in the ethylene receptor gene $(D c$ ETR $1 n r$ ) can confer ethylene insensitivity and depression of autocatalytic ethylene production in Torenia transgenic plants. This strategy should be useful for delaying flower senescence and preventing bursts of ethylene production in response to environmental cues such as wounding or pollination.

\section{Literature Cited}

Abeles, F. B., P. W. Morgan and M. E. Saltveit, Jr. 1992. Ethylene in plant biology. Academic Press, Inc., New York.

Adams-Phillips, L., C. Barry and J. Giovannoni. 2004. Signal transduction systems regulating fruit ripening. Trends Plant Sci. 9: 331-338.

Ahmadi, N., H. Mibus and M. Serek. 2008. Isolation of an ethyleneinduced putative nucleotide laccase in miniature roses (Rosa hybrida L.). J. Plant Growth Regul. 27: 320-330.

Aida, R. 2008. Torenia fournieri (torenia) as a model plant for transgenic studies. Plant Biotechnol. 25: 541-545.

Aida, R., T. Yoshida, K. Ichimura, R. Goto and M. Shibata. 1998. Extension of flower longevity in transgenic torenia plants incorporating ACC oxidase transgene. Plant Sci. 138: 91-101.

Bleecker, A. B., M. A. Estelle, C. Somerville and H. Kende. 1988. Insensitivity to ethylene conferred by a dominant mutation in Arabidopsis thaliana. Science 241: 1086-1089.

Bovy, A. G., G. C. Angenent, H. J. M. Dons and A. C. van Altvorst. 1999. Heterologous expression of the Arabidopsis etrl-1 
allele inhibits the senescence of carnation flowers. Mol. Breeding 5: 301-308.

Chang, C., S. F. Kwok, A. B. Bleecker and E. Meyerowitz. 1993. Arabidopsis ethylene-response gene ETR1: Similarity of product to two-component regulators. Science 262: 539-544.

Clark, D. G., E. K. Gubrium, J. E. Barrett, T. A. Nell and H. J. Klee. 1999. Root formation in ethylene-insensitive plants. Plant Physiol. 121: 53-60.

Clarke, S. J., M. J. McKenzie, D. J. Burritt, P. L. Guy and P. E. Jameson. 1999. Influence of white clover mosaic potexvirus infection on the cytokinin content of bean. Plant Physiol. 120: 547-552.

Cui, M. L., K. Takada, B. Ma and H. Ezura. 2004. Overexpression of a mutated melon ethylene receptor gene $\mathrm{Cm}-\mathrm{ETR} 1 / \mathrm{H} 69 \mathrm{~A}$ confers reduced ethylene sensitivity in a heterologous plant, Nemesia strumosa. Plant Sci. 167: 253-258.

Goto, R., R. Aida, M. Shibata and K. Ichimura. 1999. Role of ethylene on flower senescence of Torenia. J. Japan. Soc. Hort. Sci. 68: 263-268.

Hackett, R. M., C. W. Ho, Z. F. Lin, H. C. C. Foote, R. G. Fray and D. Grierson. 2000. Antisense inhibition of the $\mathrm{Nr}$ gene restores normal ripening to the tomato Never-ripe mutant, consistent with the ethylene receptor-inhibition model. Plant Physiol. 124: 1079-1086.

Halevy, A. H. and S. Mayak. 1981. Senescence and postharvest physiology of cut flowers, Part 2. Hort. Rev. 3: 59-143.

Higuchi, R., B. Krummel and R. K. Sakaki. 1988. A general method of in vitro preparation and specific mutagenesis of DNA fragments: Study of protein and DNA interactions. Nucl. Acids Res. 16: 7351-7367.

Ho, S. N., H. D. Hunt, R. M. Horton, J. K. Pullen and L. R. Pease. 1989. Site-directed mutagenesis by overlap extension using the polymerase chain reaction. Gene 77 : 51-59.

Hua, J. and E. M. Meyerowitz. 1998. Ethylene responses are negatively regulated by a receptor gene family in Arabidopsis thaliana. Cell 94: 261-271.

Hua, J., H. Sakai, S. Nourizadeh, Q. G. Chen, A. B. Bleecker, J. R. Ecker and E. M. Meyerowitz. 1998. EIN4 and ERS2 are members of the putative ethylene receptor gene family in Arabidopsis. Plant Cell 10: 1321-1332.

Kende, H. 1993. Ethylene biosynthesis. Ann. Rev. Plant Physiol. Plant Mol. Biol. 44: 283-307.

Klee, H. J. 2002. Control of ethylene-mediated processes in tomato at the level of receptors. J. Exp. Bot. 53: 2057-2063.

Langston, B. J., S. Bai and M. L. Jones. 2005. Increases in DNA fragmentation and induction of a senescence-specific nuclease are delayed during corolla senescence in ethylene-insensitive (etr1-1) transgenic petunias. J. Exp. Bot. 56: 15-23.

Nagata, M., N. Tanikawa, T. Onozaki and H. Mori. 2000. Ethylene receptor gene (ETR) homolog from carnation. J. Japan. Soc.
Hort. Sci. 69 (Suppl. 1): 407 (In Japanese).

Ohtsubo, N., I. Mitsuhara, M. Koga, S. Seo and Y. Ohashi. 1999. Ethylene promotes the necrotic lesion formation and basic PR gene expression in TMV-infected tobacco. Plant Cell Physiol. 40: 808-817.

Rodriguez, F. I., J. J. Esch, A. E. Hall, B. M. Binder, E. G. Schaller and A. B. Bleecker. 1999. A copper cofactor for the ethylene receptor ETR1 from Arabidopsis. Science 283: 396-398.

Sakai, H., J. Hua, Q. G. Chen, C. Chang, L. J. Medrano, A. B. Bleecker and E. M. Meyerowitz. 1998. ETR2 is an ETR1like gene involved in ethylene signaling in Arabidopsis. Proc. Natl. Acad. Sci. USA. 95: 5812-5817.

Sanikhani, M., H. Mibus, B. M. Stummann and M. Serek. 2008. Kalanchoe blossfeldiana plants expressing the Arabidopsis etr $1-1$ allele show reduced ethylene sensitivity. Plant Cell Rep. 27: 729-737.

Schaller, G., A. Ladd, M. Lanahan, J. Spanbauer and A. B. Bleecker. 1995. The ethylene response mediator ETR1 from Arabidopsis forms a disulfide linked dimer. J. Biol. Chem. 270: 12526-12530.

Shaw, J. F., H. H. Chen, M. F. Tsai, C. I. Kuo and L. C. Huang. 2002. Extended flower longevity of Petunia hybrida plants transformed with boers, a mutated ERS gene of Brassica oleracea. Mol. Breeding 9: 211-216.

Shibuya, K., M. Nagata, N. Tanikawa, T. Yoshioka, T. Hashiba and S. Satoh. 2002. Comparison of mRNA levels of three ethylene receptors in senescing flowers of carnation (Dianthus caryophyllus L.). J. Exp. Bot. 53: 399-406.

Singh, A., K. B. Evensen and T. H. Kao. 1992. Ethylene synthesis and floral senescence following compatible and incompatible pollinations in Petunia inflata. Plant Physiol. 99: 38-45.

Sriskandarajah, S., H. Mibus and M. Serek. 2007. Transgenic Campanula carpatica plants with reduced ethylene sensitivity. Plant Cell Rep. 26: 805-813.

Tanase, K., T. Onozaki, S. Satoh, M. Shibata and K. Ichimura. 2008. Differential expression levels of ethylene biosynthetic pathway genes during senescence of long-lived carnation cultivars. Postharvest Biol. Technol. 47: 210-217.

Wilkinson, J. Q., M. B. Lanahan, D. G. Clark, A. B. Bleecker, C. Chang, E. M. Meyerowitz and H. J. Klee. 1997. A dominant mutant receptor from Arabidopsis confers ethylene insensitivity in heterologous plants. Nat. Biotechnol. 15: 444-447.

Wilkinson, J. Q., M. B. Lanahan, H. C. Yen, J. Giovannoni and H. J. Klee. 1995. An ethylene-inducible component of signal transduction encoded by Never-ripe. Science 270: $1807-$ 1809.

Woltering, E. J. and W. G. vanDoorn. 1988. Role of ethylene in senescence of petals-Morphological and taxonomical relationship. J. Exp. Bot. 39: 1605-1616. 